Kumawula, Vol. 4, No.1, April 2021, Hal 23 - 37 DOI: https://doi.org/10.24198/kumawula.v4i1.29898

ISSN 2620-844X (online)

Tersedia online di http://jurnal.unpad.ac.id/kumawula/index

\title{
SOSIALISASI PENANGANAN COVID-19 DENGAN PROGRAM TELEHEALTH DI KELURAHAN CIBEUREUM KOTA CIMAHI
}

\author{
Sherly Ayuna Putri ${ }^{*}$, Hazar Kusmayanti ${ }^{2}$ \\ ${ }^{1}$ Fakultas Hukum (Universitas Padjadjaran.) \\ ${ }^{2}$ Fakultas Hukum (Universitas Padjadjaran.) \\ *Korespondensi: sherly.ayunaputri@yahoo.com
}

\begin{abstract}
Since the beginning of the spread of COVID-19 in Indonesia, Indonesia has recorded 100,303 positive cases of COVID-19. This means there needs to be an action to handle and prevent the spread of COVID-19. One of the efforts initiated by Padjadjaran University as a formula of public health prevention and surveillance to prevent and overcome the COVID-19 virus is by launching the ADA AMARI COVID-19 program. The ADA AMARI program is organized to develop a model for a community response system through education and monitoring of high-risk populations that has been integrated into the local health system. In this activity, lecturers and students join to become volunteers to make efforts to empower and provide services for people to prepare for COVID-19. One of the targets of this activity is the residents of Cimahi City, Cibeureum Village. This data collection uses the REDCap application as a secure web-based application for creating and managing online-based surveys and databases. In the REDCap application, there is an ADA AMARI COVID-19 survey which aims to detect the state of public health and find out population mortality data. Given that an understanding of the REDCap application and the ADA AMARI COVID-19 survey is important for activity participants to have and they are not familiar with these two things, it is necessary to hold outreach to each cadre of Cibeureum village.
\end{abstract}

Keywords: ADA AMARI COVID-19; Handling; Socialitation.

\begin{abstract}
ABSTRAK
Sejak awal masa penyebaran COVID-19 di Indonesia, tercatat hingga saat ini Indonesia telah menyumbang 100.303 angka kasus positif COVID-19. Hal ini menunjukan perlu adanya suatu tindakan penanganan serta pencegahan penyebaran COVID-19. Salah satu upaya yang digagas Universitas Padjadjaran sebagai bentuk pencegahan dan pengawasan kesehatan masyarakat untuk mencegah dan menanggulangi virus COVID-19 adalah dengan meluncurkan program ADA AMARI COVID-19. Program ADA AMARI COVID-19 diselenggarakan untuk mengembangkan model sistem respon masyarakat melalui pendidikan dan pemantauan penduduk berisiko tinggi yang telah diintegrasikan ke dalam sistem kesehatan setempat. Pada kegiatan ini dosen dan mahasiswa bergabung menjadi relawan untuk melakukan upaya pemberdayaan dan memberikan layanan bagi masyarakat yang siaga COVID-19. Salah satu sasaran kegiatan ini adalah warga Kota Cimahi, Kelurahan Cibeureum. Pendataan ini menggunakan aplikasi REDCap sebagai aplikasi berbasis web yang aman untuk membuat dan mengatur survei dan database berbasis online. Di dalam aplikasi REDCap terdapat survei ADA AMARI COVID19 yang bertujuan untuk mendeteksi keadaan kesehatan masyarakat dan mengetahui data mortalitas penduduk. Mengingat bahwa pemahaman mengenai aplikasi REDCap dan survei ADA AMARI COVID-19 ini penting untuk dimiliki oleh peserta kegiatan dan belum familiernya kedua hal tersebut maka perlu diadakan sosialisasi kepada masing-masing kader kelurahan Cibeureum.
\end{abstract}

Kata Kunci: ADA AMARI COVID-19; Penanganan; Sosialisasi. 


\section{PENDAHULUAN}

Pada awal 2020, dunia digemparkan dengan merebaknya virus baru dan membahayakan yaitu coronavirus jenis baru (SASRS-CoV-2) dan penyakitnya disebut Coronavirus disease 2019 (Covid-19). Menurut WHO (2020), COVID-19 merupakan penyakit menular yang disebabkan oleh jenis coronavirus yang baru ditemukan. Virus ini pertama kali mewabah di Wuhan, Tiongkok pada Desember 2019 yang saat ini telah menyebar secara global ke berbagai penjuru dunia sehingga disebut juga sebagai pandemi. Virus ini dapat menyerang siapa saja, baik balita, anak-anak, orang dewasa, orang tua, ibu hamil, maupun ibu yang sedang menyusui (Lawrenche et al., 2020). Virus ini telah memakan banyak korban jiwa termasuk di Indonesia (Gunawan \& Kusuma, 2021). Berdasarkan data yang diambil dari worldometers.com per tanggal 27 Juli 2020 yaitu telah ditemukan sebanyak 16.522.296 kasus positif di seluruh dunia, tidak terkecuali di Indonesia yang menyumbang angka 100.303 kasus positif COVID-19. Presiden Jokowi mengambil tindakan cepat dengan mengumumkan langkah-langkah pencegahan penyebaran COVID-19 karena ahli kesehatan dinilai lamban, saat itu Jokowi memerintahkan kepala daerah mulai Provinsi hingga kabupaten dan kota menetapkan situasi penyebaran COVID-19 di wilayahnya dengan berkonsultasi bersama Badan Nasional Penanggulangan Bencana (BNPB)

Salah satu upaya yang diinisiasi oleh Universitas Padjajaran sebagai bentuk pencegahan dan monitoring kesehatan masyarakat dalam mencegah dan menanggulangi virus COVID-19 ialah dengan meluncurkan program ADA AMARI COVID19. Program ADA AMARI COVID-19 ini diadakan untuk mengembangkan model sistem respons masyarakat dengan cara edukasi dan pelacakan untuk populasi yang memiliki resiko tinggi dan telah terintegrasi dengan sistem kesehatan daerah setempat (amari.unpad.id). Program ADA AMARI COVID-19 ini menjadi bentuk KKN Kemanusiaan yang dilaksanakan Universitas Padjadjaran. Kegiatan ini berfokus pada 2 daerah utama yaitu Kecamatan Jatinangor, Kabupaten Sumedang dan Kota Cimahi. Kota Cimahi sendiri terdiri dari 15 kelurahan yang tersebar di 3 Kecamatan. Salah satu yang menjadi sorotan adalah Kelurahan Cibeureum.

Kelurahan Cibeureum terletak di Kecamatan Cimahi Selatan bersama 4 (empat) kelurahan lainnya (Pemerintah Kota Cimahi, n.d.). Kelurahan Cibeureum memiliki luas wilayah sebesar 2,75 $\mathrm{Km}^{2}$ dengan 29 Rukun Warga (RW) dan 171 Rukun Tetangga (RT) di Kelurahan Cibeureum. Jumlah penduduk di Kelurahan Cibeureum per tahun 2018 adalah 69.116 orang yang terdiri dari 20.760 rumah tangga dengan rata-rata anggota rumah tangga sebanyak 4 orang (BPS Kota Cimahi, 2018).

Kelurahan ini telah menyediakan fasilitas layanan kesehatan untuk memastikan kualitas kesehatan dari warganya. Menurut publikasi Badan Pusat Statistik (BPS) Kota Cimahi yang berjudul "Kecamatan Cimahi Selatan dalam Angka 2018", Kelurahan Cibeureum per tahun 2018 memiliki 2 (dua) Puskesmas. Selain itu, terdapat sarana kesehatan lainnya, yaitu 10 (sepuluh) tempat praktek dokter, 15 (lima belas) tempat praktek bidan, 6 (enam) apotik, 1 (satu) toko obat, dan 2 (dua) balai pengobatan. Berkaitan dengan angka kasus positif COVID-19, Kelurahan Cibeureum memegang angka kasus positif tertinggi di Kota Cimahi per tanggal 24 Juli 2020 (Pusat Informasi COVID-19 Kota Cimahi, 2020). Dari 117 kasus positif, 17 diantaranya berasal dari Kelurahan Cibeureum.

Sebagai langkah awal dari kegiatan KKN ini, dilakukan pertemuan dengan PIC (Person in Charge) Puskesmas Kelurahan Cibeureum. melakukan diskusi dan pemaparan mengenai program ADA-AMARI COVID-19 dengan Kepala Puskesmas dr. Mami Rosmala Dewi dan Kepala Sub Bagian Tata Usaha Enri Rosnadiyanti, SKM. Dari pertemuan ini juga kami dapat mengetahui informasi mengenai 
keadaan masyarakat di Kelurahan Cibeureum terkait COVID-19.

Informasi yang didapat diantaranya mengenai rentang usia masyarakat yang telah terpapar COVID-19 yaitu mulai dari 18 tahun hingga 61 tahun. Menurut keterangan dr. Mami, tingginya kasus positif COVID-19 di Kelurahan Cibeureum dapat terjadi akibat kurangnya kesadaran masyarakat dalam menerapkan protokol kesehatan. Hasil lain dari pertemuan ini yaitu pembuatan grup WhatsApp untuk mempermudah koordinasi antar seluruh pihak yang terlibat. Grup ini beranggotakan para kader perwakilan setian RW beserta mahasiswa/mahasiswi KKN dan Dosen Pembimbing Lapangan (DPL).

Berdasarkan fakta yang ditemukan di lapangan, terdapat program yang dapat dilaksanakan sebagai bentuk pengabdian kepada masyarakat. Rangkaian program pengabdian ini diawali dengan melakukan sosialisasi kepada para kader perwakilan dari setiap RW yang ada di Kelurahan Cibeureum secara tatap muka. Hal tersebut dilakukan berdasarkan beberapa pertimbangan diantaranya kemudahan dalam memahami materi bagi para kader karena dapat melakukan tanya jawab dan praktek secara langsung serta memudahkan bagi para kader yang memiliki permasalahan pada akses teknologi dan internet. Tanpa melupakan protokol kesehatan, kegiatan sosialisasi ini dibagi menjadi 3 kloter dengan pertimbangan yaitu membatasi jumlah peserta yang hadir di setiap sesi-nya. Kader tentunya diharapkan bisa memahami cara penggunaan RedCap dan cara pengisian formulir "Identifikasi Dini Kondisi dan Status Kesehatan Warga Kota Cimahi” karena mereka yang akan menjadi perantara penghubung antara mahasiswa/mahasiswi KKN dengan masyarakat.

Kemudian program pengabdian dilanjutkan dengan penyebaran formulir "Identifikasi Dini Kondisi dan Status Kesehatan Warga Kota Cimahi" kepada masyarakat Kelurahan Cibeureum. Formulir ini disebarkan oleh mahasiswa/mahasiswi melalui grup WhatsApp yang telah dibuat kepada kader perwakilan setiap RW yang kemudian akan disebarkan di grup RW-nya masing-masing. Penyebaran formulir secara daring tentu akan memudahkan kader dalam menjangkau ke masyarakat, meminimalisir penggunaan kertas, dan meminimalisir adanya pertemuan tatap muka maupun kontak langsung antar masyarakat mengingat kasus positif COVID-19 di Cimahi khususnya Kelurahan Cibeureum masih tergolong tinggi.

Setelah melakukan penyebaran formulir, program pengabdian ini dilanjutkan dengan validasi dan cleaning data, serta pengolahan data hasil survei kondisi kesehatan masyarakat Kelurahan Cibeureum, Kota Cimahi yang telah disebar sebelumnya. Hal ini dilakukan agar mengetahui data mana yang sudah valid maupun yang invalid sehingga dapat dilakukan validasi pada warga yang bersangkutan agar data yang didapatkan lengkap dan sesuai dengan kebutuhan. Pengolahan data juga menjadi poin penting yang harus dilakukan. Karena dari data yang diolah kita dapat mengetahui kondisi kesehatan masyarakat yang nantinya dapat digolongkan menjadi beberapa kategori seperti berdasarkan usia, jumlah anggota keluarga, maupun kondisi kesehatan lain yang dialami masyarakat.

Dari data yang diolah tersebut, didapatkan hasil sebanyak 516 data Kartu Keluarga (KK) valid terkumpul per Jumat, 31 Juli 2020. Jumlah tersebut setara dengan 1157 data individual. Hasil pendataan ini nantinya dapat digunakan sebagai arsip bagi kelurahan setempat sebagai upaya pendeteksian penyakit secara cepat dengan meminimalisir petugas untuk terjun langsung ke lapangan sehingga masih memperhatikan protokol kesehatan. Hasil pendataan ini juga dapat digunakan untuk merancang program telehealth atau pengiriman layanan kesehatan secara jarak jauh melalui teknologi informasi dan komunikasi oleh bantuan dokter muda di Rumah Sakit Hasan Sadikin (RSHS) yang bekerjasama dengan Universitas Padjadjaran. 


\section{METODE}

KKN ADA AMARI COVID-19 Universitas Padjadjaran dilaksanakan melalui dua cara, yaitu utamanya menggunakan media komunikasi daring (online), dan dikombinasikan dengan kegiatan di lokasi sesuai dengan kebutuhan. Kegiatan-kegiatan yang dilakukan secara daring yang membutuhkan komunikasi menggunakan bantuan aplikasi berbalas pesan (seperti WhatsApp dan Line) dan video conference dan video call (seperti Zoom dan Google Meet). Aplikasi lain yang digunakan adalah Trello yang bertujuan untuk mendata kegiatan harian kelompok sebagai bahan laporan kepada pihak ADA AMARI COVID-19 Unpad. Untuk pengumpulan data survei kondisi kesehatan dan pelaporan kegiatan harian individu, digunakan REDCap yaitu sistem pengumpul data daring yang telah disesuaikan sesuai dengan tujuan dan kebutuhan program ADA AMARI COVID-19. Kegiatan yang harus bertatap muka secara langsung adalah kegiatan seputar sosialisasi, mulai dari survei lapangan hingga pelaksanaan sosialisasi. Penyuluhan ini dilakukan dengan merujuk ketentuan Keputusan Presiden Republik Indonesia No 7 Tahun 2020 Tentang Gugus Tugas Percepatan Penanggulangan Corona Virus, Peraturan Menteri Dalam Negeri Nomor 20 Tahun 2020 Tentang Percepatan Penanganan Corona Virus Dalam Lingkungan Pemerintah Daerah.

Teknis pembagian kerja antara mahasiswa KKN ini adalah membagi antara tim yang turun ke lapangan dan tim yang tidak turun ke lapangan. Pada dasarnya tim lapangan memiliki tugas utama untuk melakukan sosialisasi tatap muka kepada masyarakat, sedangkan tim yang tidak turun ke lapangan bertugas untuk membantu persiapannya. Dalam pelaksanaannya, pembagian tugas ini cenderung berjalan fleksibel dan sesuai dengan kebutuhan yang ada. Contohnya adalah kegiatan validasi data juga dilakukan oleh tim yang tidak turun ke lapangan.

\section{HASIL DAN PEMBAHASAN}

Tahap Persiapan

Tahap persiapan ini berisi beberapa kegiatan yang menjadi awalan kegiatan KKN ini sebelum kegiatan utama dilakukan pada tahap pelaksanaan. Kegiatan ini dimulai dengan diadakannya pertemuan daring pertama Kelompok KKN ADA AMARI COVID-19 Kelurahan Cibeureum, Kota Cimahi yang merupakan pertemuan pertama anggota dan DPL kelompok KKN Kelurahan Cibeureum. Tujuan pertemuan daring ini adalah untuk melakukan perkenalan satu sama lain. Pembahasan dimulai dengan perkenalan, lalu berlanjut ke diskusi mengenai KKN ADA AMARI COVID-19. Diskusi ini adalah seputar tujuan KKN ini serta tugas utama kami untuk membantu pihak ADA AMARI COVID-19 Unpad dalam membantu menyebarkan formulir survei kondisi kesehatan warga Kelurahan Cibeureum di masa pandemi COVID-19 ini. Hasil diskusi ini memunculkan kebutuhan untuk mengadakan sosialisasi kepada perwakilan warga Kelurahan Cibeureum yang selanjutnya disebut sebagai kader. Sosialisasi kegiatan KKN ADA AMARI COVID-19 ini utamanya dilakukan agar kader mengetahui tujuan dan tata cara pengisian link aplikasi REDCap.

Dengan mempertimbangkan kondisi yang ada, kami membagi tim menjadi tim yang turun ke lapangan untuk melakukan sosialisasi tatap muka kepada masyarakat dan tim yang tidak turun ke lapangan. Kami berdiskusi lebih lanjut untuk menentukan waktu sosialisasi dan rencana yang akan dilakukan ketika di lapangan.

Pada tahap persiapan ini juga terdapat kegiatan yang difasilitasi oleh pihak ADA AMARI COVID-19, yaitu pelepasan kegiatan KKN pada 1 Juli 2020. Pelepasan KKN ini dihadiri oleh perwakilan kelompok, yaitu Erika Maya Sari dan Muhammad Rafif Aulia dan berisi materi mengenai KKN secara menyeluruh, misalnya seputar pengisian logbook, pembuatan laporan akhir, pembuatan video, dll. 
Sebelum benar-benar melaksanakan kegiatan, kami juga melakukan asesmen awal dan diskusi online untuk mengetahui kondisi terkini dari lokasi KKN yaitu Kelurahan Cibeureum dan yang didasarkan pada sumbersumber online seperti website resmi Kota Cimahi, dan website terkait informasi COVID19 khusus Kota Cimahi untuk memberikan gambaran awal terkait kondisi COVID-19 di Kelurahan Cibeureum, Kota Cimahi. Informasi tentang virus ini tentunya masih sangat terbatas karena banyak hal masih dalam penelitian dan data epidemiologi akan sangat berkembang juga, untuk itu tinjauan ini merupakan tinjauan berdasarkan informasi terbatas yang dirangkum dengan tujuan untuk memberi informasi dan sangat mungkin akan terdapat perubahan kebijakan.

Selama tahap persiapan ini juga dilakukan diskusi yang waktu pelaksanaannya tersebar. Diskusi dilakukan jika ada yang perlu disepakati bersama mengenai pelaksanaan KKN ke depannya. Melalui tahap diskusi ini, mahasiswa melatih skill berpikir cepat dan problem solving untuk memberikan ide mengenai solusi suatu permasalahan dalam waktu singkat, sekaligus melatih kerja sama dengan teman-teman baru yang heterogen sehingga dapat beradaptasi dengan lingkungan baru secara profesional dalam menjalankan tugas masing-masing.

\section{Tahap Pelaksanaan}

Kegiatan pengabdian masyarakat yang dilakukan pada KKN Kemanusiaan ADA AMARI COVID-19 ini adalah rangkaian kegiatan yang bertujuan untuk menyebarkan survei kondisi kesehatan kepada masyarakat. Di bawah supervisi dosen, program ini dilaksanakan oleh mahasiswa yang mengikuti KKN kemanusiaan ini.

Tabel 1. Uraian Tahap Pelaksanaan Program KKN ADA AMARI COVID-19

\begin{tabular}{|c|c|}
\hline $\begin{array}{l}\text { Sosialisasi progr } \\
\text { Cibeureum }\end{array}$ & n KKN ADA AMARI COVID-19 kepada pihak PIC Kelurahan \\
\hline Jenis Kegiatan & $\begin{array}{l}\text { Pertemuan tatap muka dalam kelompok kecil secara informal dengan PIC } \\
\text { Kelurahan Cibeureum }\end{array}$ \\
\hline $\begin{array}{l}\text { Tujuan dan } \\
\text { Manfaat }\end{array}$ & $\begin{array}{l}\text { 1. Melakukan pengenalan pertama dengan Kelurahan Cibeureum } \\
\text { mengenai program KKN ADA AMARI COVID-19 } \\
\text { 2. Meminta pihak PIC Puskesmas Kelurahan Cibeureum untuk menjadi } \\
\text { penghubung antara kader Kelurahan Cibeureum }\end{array}$ \\
\hline Sasaran Kegiatan & PIC Puskesmas Kelurahan Cibeureum \\
\hline $\begin{array}{l}\text { Waktu } \\
\text { Pelaksanaan }\end{array}$ & Senin, 6 Juli 2020 \\
\hline $\begin{array}{l}\text { Pihak yang } \\
\text { Terlibat }\end{array}$ & $\begin{array}{l}\text { 1. PIC Puskesmas Cibeureum } \\
\text { 2. Dosen Pembimbing Lapangan (DPL) } \\
\text { 3. Mahasiswa/Mahasiswi KKN ADA-AMARI COVID-19 }\end{array}$ \\
\hline Proses Pelaksanaan & $\begin{array}{l}\text { Proses sosialisasi kepada pihak PIC Puskesmas diawali dengan } \\
\text { pemaparan mengenai program KKN ADA AMARI COVID-19. Pihak PIC } \\
\text { Puskesmas sudah dihubungi sebelumnya oleh tim ADA AMARI COVID- } \\
10 \text { sehingga proses ini tidak dilakukan sangat mendetail. }\end{array}$ \\
\hline
\end{tabular}




\begin{tabular}{|c|c|}
\hline & $\begin{array}{l}\text { PIC Puskesmas juga menjelaskan berbagai macam kondisi yang ada di } \\
\text { Kelurahan Cibeureum, salah satunya adalah mengenai fakta bahwa } \\
\text { Kelurahan Cibeureum saat ini tengah menjadi daerah yang sedang diawasi } \\
\text { ketat karena adanya pandemi ini. Menurut PIC puskesmas, Kelurahan } \\
\text { Cibeureum menjadi salah satu kelurahan yang memiliki jumlah kasus } \\
\text { COVID-19 tertinggi di Kota Cimahi dan berstatus zona merah. Diskusi ini } \\
\text { juga menjadi media asesmen awal karena PIC Puskesmas lebih mengetahui } \\
\text { keadaan Kelurahan Cibeureum, baik mengenai kondisi wilayah Kelurahan } \\
\text { Cibeureum maupun kondisi masyarakat di daerah tersebut. } \\
\text { Terakhir, PIC Puskesmas meminta Kelompok KKN ini untuk membuat } \\
\text { grup WhatsApp yang akan disambungkan dengan beberapa kader dari } \\
\text { setiap RW di Kelurahan Cibeureum guna untuk memudahkan koordinasi. }\end{array}$ \\
\hline $\begin{array}{l}\text { Hasil Capaian } \\
\text { Kegiatan }\end{array}$ & $\begin{array}{l}\text { 1. Mengenal pihak PIC Puskesmas Kelurahan Cibeureum } \\
\text { 2. PIC Puskesmas Kelurahan Cibeureum memahami tujuan dan proses } \\
\text { pelaksanaan program KKN ADA AMARI COVID-19 } \\
\text { 3. Terbentuknya grup WhatsApp yang memudahkan koordinasi antara } \\
\text { pihak KKN ADA AMARI COVID-19, PIC Puskesmas, dan kader } \\
\text { Kelurahan Cibeureum }\end{array}$ \\
\hline $\begin{array}{l}\text { Rancangan Tindak } \\
\text { Lanjut Hasil } \\
\text { Kegiatan }\end{array}$ & $\begin{array}{l}\text { Melakukan sosialisasi kepada kader Kelurahan Cibeureum mengenai } \\
\text { program KKN ADA AMARI COVID-19 ini, terutama mengenai formulir } \\
\text { survei kondisi kesehatan }\end{array}$ \\
\hline \multicolumn{2}{|c|}{ Sosialisasi program KKN ADA AMARI COVID-19 kepada kader Kelurahan Cibeureum } \\
\hline Jenis Kegiatan & $\begin{array}{l}\text { Sosialisasi tatap muka formal dengan kader Kelurahan Cibeureum. } \\
\text { Kegiatan ini banyaknya berisi pemaparan materi. }\end{array}$ \\
\hline $\begin{array}{l}\text { Tujuan dan } \\
\text { Manfaat }\end{array}$ & $\begin{array}{l}\text { 1. Memberi pemahaman mengenai program ADA-AMARI COVID- } \\
19 \text {. } \\
\text { 2. Memberi pemahaman mengenai tata cara pengisian survei } \\
\text { "Identifikasi Dini Kondisi dan Status Kesehatan Warga Kota } \\
\text { Cimahi" secara baik dan benar. }\end{array}$ \\
\hline Sasaran Kegiatan & Kader dari setiap RW yang ada di Kelurahan Cibeureum \\
\hline $\begin{array}{l}\text { Waktu } \\
\text { Pelaksanaan }\end{array}$ & $\begin{array}{l}\text { Kloter 1: Senin, } 13 \text { Juli } 2020 \text { pukul } 12.30-14.25 \text { WIB } \\
\text { Kloter 2: Selasa, } 14 \text { Juli } 2020 \text { pukul } 12.30-14.25 \text { WIB } \\
\text { Kloter 3: Selasa, } 14 \text { Juli } 2020 \text { pukul } 15.30-17.10 \text { WIB }\end{array}$ \\
\hline $\begin{array}{l}\text { Pihak yang } \\
\text { Terlibat }\end{array}$ & $\begin{array}{l}\text { 1. Kecamatan Cimahi Selatan } \\
\text { 2. PIC Puskesmas Kelurahan Cibeureum } \\
\text { 3. Kader perwakilan setiap RW } \\
\text { 4. Dosen Pembimbing Lapangan (DPL) } \\
\text { 5. Mahasiswa/Mahasiswi KKN ADA-AMARI COVID-19 }\end{array}$ \\
\hline Proses Pelaksanaan & $\begin{array}{l}\text { Sosialisasi ini dimulai dengan memberikan penjelasan singkat mengenai } \\
\text { ADA-AMARI yang berisi tentang pengertian, tujuan, manfaat, tata cara } \\
\text { pelaksanaan, dan penggunaan program RedCap untuk pengumpulan data. }\end{array}$ \\
\hline
\end{tabular}




\begin{tabular}{|c|c|}
\hline & $\begin{array}{l}\text { Kemudian kegiatan ini dilanjutkan dengan simulasi/praktek pengisian } \\
\text { survei "Identifikasi Dini Kondisi dan Status Kesehatan Warga Kota } \\
\text { Cimahi" secara lengkap dan benar. Untuk membantu mempermudah para } \\
\text { kader dalam menyebarkan dan mensosialisasikan program ini kepada } \\
\text { masyarakat, kami juga membekali para kader dengan panduan pengisian } \\
\text { survei baik dalam bentuk video maupun tertulis yang dapat langsung } \\
\text { dibagikan kepada masyarakat (tertera pada lampiran). }\end{array}$ \\
\hline $\begin{array}{l}\text { Hasil Capaian } \\
\text { Kegiatan }\end{array}$ & $\begin{array}{l}\text { Setiap Kader RW mampu menggunakan program RedCap sebagai alat } \\
\text { pengumpul data sekaligus mampu menyebarkan dan mensosialisasikan } \\
\text { survei ini kepada masyarakat setempat, khususnya RW masing-masing. }\end{array}$ \\
\hline $\begin{array}{l}\text { Rancangan Tindak } \\
\text { Lanjut Hasil } \\
\text { Kegiatan }\end{array}$ & $\begin{array}{l}\text { 1. Penyebaran formulir survei kondisi kesehatan kepada masyarakat } \\
\text { Kelurahan Cibeureum melalui kader tiap RW } \\
\text { 2. Pembuatan panduan pengisian link survei oleh tim yang tidak turun } \\
\text { ke lapangan }\end{array}$ \\
\hline \multicolumn{2}{|c|}{$\begin{array}{l}\text { Penyebaran formulir survei kondisi kesehatan kepada masyarakat Kelurahan } \\
\text { Cibeureum, Kota Cimahi }\end{array}$} \\
\hline Jenis Kegiatan & Penyebaran formulir survei secara daring \\
\hline $\begin{array}{l}\text { Tujuan dan } \\
\text { Manfaat }\end{array}$ & $\begin{array}{l}\text { Memeroleh data kondisi kesehatan masyarakat Kelurahan Cibeureum, } \\
\text { Kota Cimahi }\end{array}$ \\
\hline Sasaran Kegiatan & Masyarakat Kelurahan Cibeureum, Kota Cimahi \\
\hline $\begin{array}{l}\text { Waktu } \\
\text { Pelaksanaan }\end{array}$ & Rabu, 15 Juli 2020 s.d. Selasa, 30 Juli 2020 \\
\hline $\begin{array}{l}\text { Pihak yang } \\
\text { Terlibat }\end{array}$ & $\begin{array}{l}\text { 1. Kader perwakilan setiap RW } \\
\text { 2. Dosen Pembimbing Lapangan (DPL) } \\
\text { 3. Mahasiswa/Mahasiswi KKN ADA-AMARI COVID-19 }\end{array}$ \\
\hline Proses Pelaksanaan & $\begin{array}{l}\text { Penyebaran formulir survei kondisi kesehatan ini dilakukan dengan cara } \\
\text { menghubungi kader tiap RW dan meminta kader untuk menyebarkan } \\
\text { kepada warga di RW-nya. Dengan jumlah kader yang cukup banyak, kami } \\
\text { membagi 2-3 kader tiap mahasiswa untuk dihubungi. }\end{array}$ \\
\hline $\begin{array}{l}\text { Hasil Capaian } \\
\text { Kegiatan }\end{array}$ & $\begin{array}{l}\text { Diperolehnya data kondisi kesehatan masyarakat Kelurahan Cibeureum, } \\
\text { Kota Cimahi yang masih belum divalidasi }\end{array}$ \\
\hline $\begin{array}{l}\text { Rancangan Tindak } \\
\text { Lanjut Hasil } \\
\text { Kegiatan }\end{array}$ & $\begin{array}{l}\text { Data yang telah terkumpul dari masyarakat perlu untuk divalidasi dengan } \\
\text { menghubungi kader maupun masyarakatnya secara langsung, baik melalui } \\
\text { pesan elektronik maupun melalui telepon. Kemudian dilanjutkan dengan } \\
\text { melengkapi maupun mengoreksi data yang invalid dan incomplete. }\end{array}$ \\
\hline
\end{tabular}




\begin{tabular}{|c|c|}
\hline \multicolumn{2}{|c|}{$\begin{array}{l}\text { Validasi dan cleaning data, serta pengolahan data hasil survei kondisi kesehatan } \\
\text { masyarakat Kelurahan Cibeureum, Kota Cimahi }\end{array}$} \\
\hline Jenis Kegiatan & $\begin{array}{l}\text { 1. Validasi data secara daring dengan menghubungi pihak yang } \\
\text { mengisikan datanya secara tidak lengkap atau tidak valid } \\
\text { 2. Rekap data yang sudah dan belum divalidasi }\end{array}$ \\
\hline $\begin{array}{l}\text { Tujuan dan } \\
\text { Manfaat }\end{array}$ & $\begin{array}{l}\text { Memperoleh data yang sudah divalidasi sehingga bisa ditindaklanjuti oleh } \\
\text { pihak KKN ADA AMARI COVID-19 }\end{array}$ \\
\hline Sasaran Kegiatan & Warga Kelurahan Cibeureum yang memiliki data yang perlu divalidasi \\
\hline $\begin{array}{l}\text { Waktu } \\
\text { Pelaksanaan }\end{array}$ & Minggu, 26 Juli 2020 s.d. Kamis, 30 Juli 2020 \\
\hline $\begin{array}{l}\text { Pihak yang } \\
\text { Terlibat }\end{array}$ & $\begin{array}{l}\text { 1. Kader perwakilan setiap RW } \\
\text { 2. Dosen Pembimbing Lapangan (DPL) } \\
\text { 3. Mahasiswa/Mahasiswi KKN ADA-AMARI COVID-19 }\end{array}$ \\
\hline Proses Pelaksanaan & $\begin{array}{l}\text { Data yang telah terkumpul dari masyarakat direkap terlebih dahulu oleh } \\
\text { beberapa anggota kelompok kami. Rekapan data berisi data-data yang } \\
\text { tidak valid dan perlu divalidasi. Setelah terkumpul nama-nama warga yang } \\
\text { perlu dihubungi, kami melakukan validasi data dengan cara menghubungi } \\
\text { warga yang mengisikan datanya secara tidak valid tersebut. Validasi data } \\
\text { dilakukan melalui pesan elektronik maupun melalui telepon. Validasi data } \\
\text { diakhiri dengan perekapan ulang dan pelengkapan maupun pengoreksian } \\
\text { data yang invalid dan incomplete. }\end{array}$ \\
\hline $\begin{array}{l}\text { Hasil Capaian } \\
\text { Kegiatan }\end{array}$ & $\begin{array}{l}\text { Diperolehnya data yang sudah divalidasi sehingga bisa ditindaklanjuti oleh } \\
\text { pihak KKN ADA AMARI COVID-19 }\end{array}$ \\
\hline $\begin{array}{l}\text { Rancangan Tindak } \\
\text { Lanjut Hasil } \\
\text { Kegiatan }\end{array}$ & $\begin{array}{l}\text { Melaporkan rekapan data yang sudah divalidasi maupun yang tidak bisa } \\
\text { kami validasi kepada pihak ADA AMARI COVID-19 Unpad. }\end{array}$ \\
\hline
\end{tabular}

1. Hasil Capaian Kegiatan Secara Umum

Kegiatan yang telah disebutkan menghasilkan sebanyak 516 data Kartu Keluarga (KK) valid terkumpul per
Kamis, 30 Juli 2020. Berikut adalah rekapan data per hari yang diperoleh pada tanggal 13 - 30 Juli 2020.

Tabel 2. Rekapan data harian tanggal pada tanggal 13 - 30 Juli 2020

\begin{tabular}{|c|c|c|c|c|c|}
\hline Tanggal & $\begin{array}{c}\text { Jumlah } \\
\text { KK* }\end{array}$ & $\begin{array}{c}\text { Data yang } \\
\text { masuk }\end{array}$ & $\begin{array}{c}\text { Data yang } \\
\text { valid }\end{array}$ & $\begin{array}{c}\text { Data yang } \\
\text { tidak valid }\end{array}$ & $\begin{array}{c}\text { Data yang sudah } \\
\text { divalidasi }\end{array}$ \\
\hline $13 / 07 / 2020$ & 33 & 34 & 15 & 19 & 12 \\
\hline $14 / 07 / 2020$ & 63 & 28 & 11 & 17 & 10 \\
\hline
\end{tabular}




\begin{tabular}{|c|c|c|c|c|c|}
\hline $15 / 07 / 2020$ & 68 & 5 & 3 & 2 & 0 \\
\hline $16 / 07 / 2020$ & 73 & 5 & 3 & 2 & 1 \\
\hline $17 / 07 / 2020$ & 82 & 9 & 5 & 4 & 6 \\
\hline $18 / 07 / 2020$ & 121 & 39 & 20 & 19 & 2 \\
\hline $19 / 07 / 2020$ & 130 & 9 & 2 & 7 & 5 \\
\hline 20/07/2020 & 165 & 35 & 20 & 15 & 12 \\
\hline $21 / 07 / 2020$ & 206 & 41 & 29 & 12 & 10 \\
\hline $22 / 07 / 2020$ & 285 & 79 & 64 & 15 & 16 \\
\hline $23 / 07 / 2020$ & 349 & 64 & 45 & 19 & 11 \\
\hline $24 / 07 / 2020$ & 407 & 58 & 42 & 16 & 1 \\
\hline $25 / 07 / 2020$ & 447 & 40 & 30 & 10 & 0 \\
\hline 26/07/2020 & 502 & 55 & 29 & 26 & 4 \\
\hline 27/07/2020 & 509 & 7 & 4 & 3 & 0 \\
\hline $28 / 07 / 2020$ & 514 & 5 & 3 & 2 & 1 \\
\hline 29/07/2020 & 516 & 2 & 1 & 1 & 1 \\
\hline $30 / 07 / 2020$ & 516 & 0 & 0 & 0 & 0 \\
\hline
\end{tabular}

Berikut adalah olahan data yang dapat memberikan gambaran umum kondisi kesehatan masyarakat Kelurahan Cibeureum berdasarkan data dari 430 data KK yang memiliki data lengkap untuk diolah datanya. Jika dikalkulasikan, maka data tersebut setara dengan 1.157 data individual:

a. Usia

Rata-rata usia responden formulir survei ini adalah 45,01 tahun ( $\mathrm{sd}=$ 13.623). Responden paling banyak berada pada rentang usia 46-55 tahun. Persebaran usia responden dijelaskan pada tabel di bawah ini.
Tabel 3. Persebaran usia responden

\begin{tabular}{|c|c|}
\hline $\begin{array}{c}\text { Rentang Usia } \\
\text { (tahun) }\end{array}$ & $\begin{array}{c}\text { Jumlah Data } \\
\text { KK }\end{array}$ \\
\hline $15-25$ & 41 \\
\hline $26-35$ & 78 \\
\hline $36-45$ & 98 \\
\hline $46-55$ & 122 \\
\hline $56-65$ & 65 \\
\hline $66-75$ & 19 \\
\hline$>75$ & 7 \\
\hline
\end{tabular}

b. Jumlah Anggota Keluarga per KK Jumlah anggota keluarga rata-rata adalah 1,6 anggota keluarga per KK (dibulatkan menjadi 2 anggota 
keluarga per KK). Di Kelurahan Cibeureum, data KK paling banyak tidak memiliki anggota keluarga sama sekali (132 data KK). Tabel 6 menggambarkan persebaran jumlah anggota keluarga per KK.

Tabel 4. Persebaran jumlah anggota keluarga per KK

\begin{tabular}{|c|c|}
\hline $\begin{array}{c}\text { Jumlah Anggota } \\
\text { Keluarga Per KK }\end{array}$ & $\begin{array}{c}\text { Jumlah } \\
\text { Data KK }\end{array}$ \\
\hline 0 & 132 \\
\hline 1 & 61 \\
\hline 2 & 99 \\
\hline 3 & 99 \\
\hline 4 & 25 \\
\hline 5 & 13 \\
\hline 7 & 1 \\
\hline
\end{tabular}

c. Kondisi Kesehatan Responden Total responden yang teridentifikasi memiliki masalah kondisi kesehatan adalah sebanyak 14 data KK yang setara dengan total 17 orang individu bergejala. Keluhan yang dirasakan responden tidak semuanya mengarah ke gejala COVID-19. Gejala penyakit yang paling banyak dikeluhkan adalah kelelahan (5 data), disusul dengan nyeri kepala (3 orang). Keluhan lainnya adalah batuk, demam, dan diare.

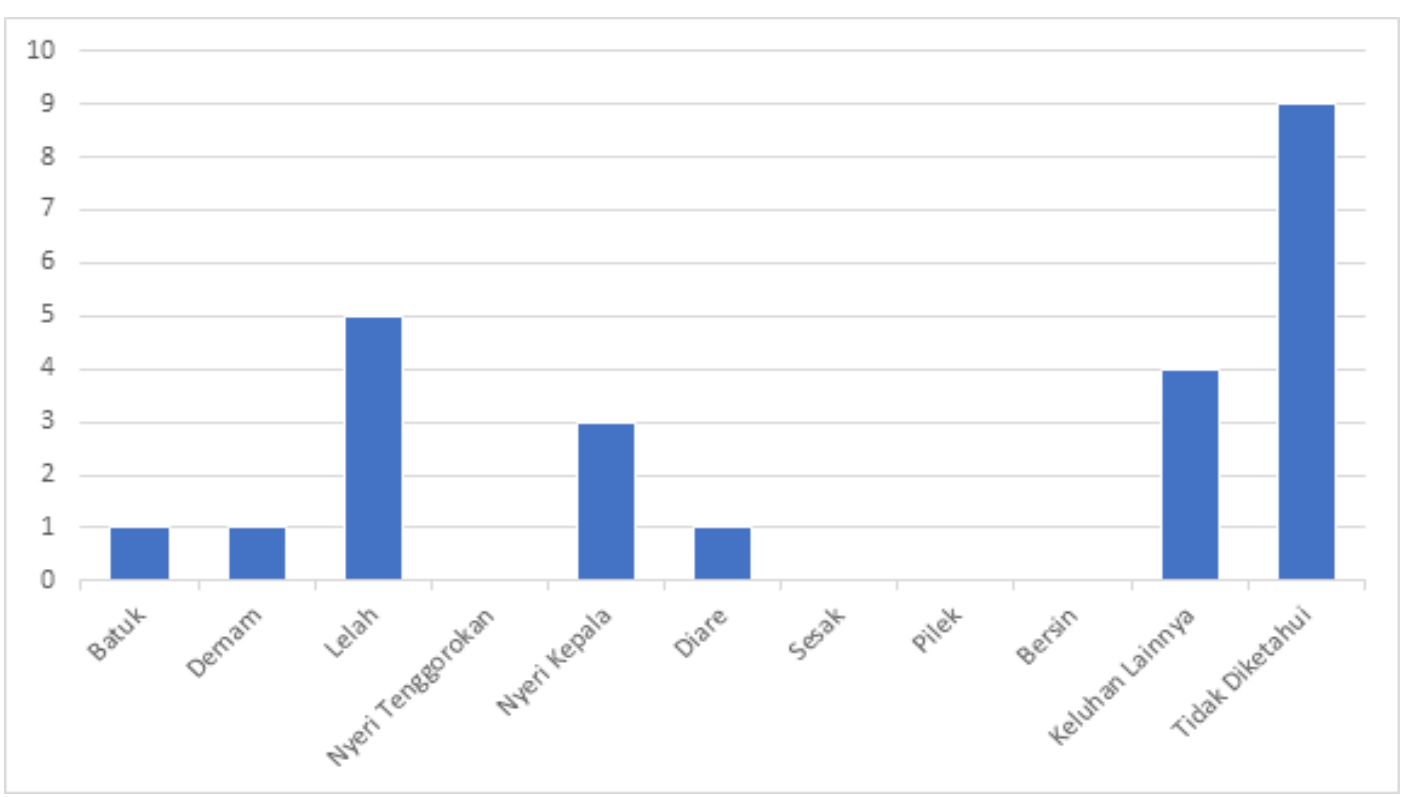

Gambar 1. Gejala yang dikeluhkan 


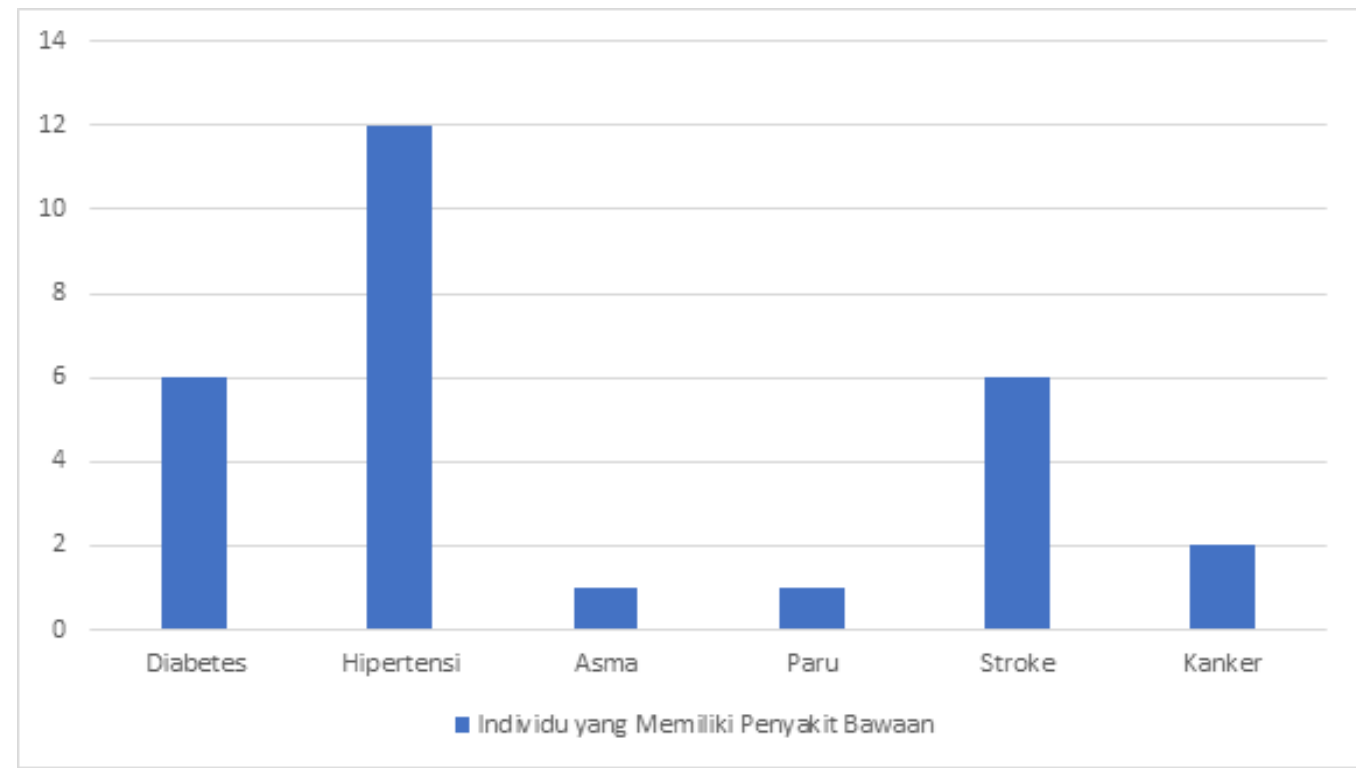

Gambar 2. Diagram penyakit bawaan responden

Selain dari gejala penyakit yang dikeluhkan responden, terdapat responden yang memiliki penyakit bawaan atau komorbid. Penyakit bawaan yang paling banyak dilaporkan adalah hipertensi (12 data), disusul dengan diabetes dan stroke (masingmasing 6 data).

\section{Rancangan Tindak Lanjut Hasil Kegiatan}

Rancangan tindak lanjut berdasarkan hasil kegiatan ini adalah untuk menyusun laporan dan dokumentasi akhir kegiatan, mengolah data untuk memperoleh gambaran mengenai kondisi kesehatan masyarakat secara umum, dan melaksanakan perpisahan dengan pihak Kelurahan Cibeureum yang menjelaskan bahwa program KKN ADA AMARI COVID-19 ini berakhir dan menjelaskan bahwa program ini akan dilanjutkan oleh pihak ADA AMARI COVID-19 dan telehealth, sekaligus memberikan laporan akhir kepada pihak puskesmas.

\section{Tindak Lanjut Kegiatan}

\section{Hasil dan Perubahan}

Kegiatan KKN yang berisi beberapa kegiatan ini menghasilkan beberapa perubahan, baik pada masyarakat maupun mahasiswa. Secara umum, kegiatan berupa penyebaran formulir survei ADA AMARI COVID-19 ini juga mencapai tujuan pemberdayaan masyarakat dari segi teknologi dan kesehatan. Secara rinci, tujuan yang telah tercapai dalam kegiatan ini dan perubahannya adalah sebagai berikut:

a. Bagi mahasiswa, kegiatan ini:

i. Meningkatkan pengetahuan mengenai masyarakat dan permasalahan sosialnya, khususnya masyarakat Kelurahan Cibeureum;

ii. Meningkatkan pengetahuan mengenai COVID-19 dengan mengikuti kursus daring mengenai COVID-19 di LiVE Unpad dan mendapatkan sertifikat pemahaman COVID-19, karena penyebaran Covid -19 yang begitu cepat dan mematikan, penularannya melalui kontak fisik ditularkan melalui mulut, mata dan hidung;

iii. Meningkatkan sikap baik terhadap nilai kemanusiaan dalam menjalankan kontak dengan masyarakat Kelurahan Cibeureum; 
iv. Meningkatkan skill empati dalam membantu menyelesaikan permasalahan sosial di masyarakat, khususnya dalam situasi pandemi COVID-19 ini,

v. Meningkatkan skill berpikir kritis dan sistematis mahasiswa dalam identifikasi potensi transmisi COVID-19 di masyarakat,

vi. Meningkatkan skill komunikasi efektif, organisasi, dan kepemimpinan.

b. Bagi warga Kelurahan Cibeureum, kegiatan ini:

i. Meningkatkan pengetahuan masyarakat Kelurahan Cibeureum mengenai COVID-19 dengan memberikan saran akses warga terhadap pengetahuan terkini dan terpercaya tentang COVID-19;

ii. Meningkatkan pengetahuan dan keterampilan pengelolaan teknologi digital (digital literacy) masyarakat Kelurahan Cibeureum;

iii. Meningkatkan perilaku partisipasi warga Kelurahan Cibeureum dalam penanggulangan COVID-19.

\section{Permasalahan atau Hambatan yang} Ditemui

KKN ini memiliki beberapa permasalahan atau hambatan yang terjadi seiring proses berjalannya kegiatan, yaitu sebagai berikut:

a. Ketika mendata kader, terdapat beberapa RW yang tidak mengirimkan kader sama sekali sebanyak 4 RW.

b. Kontak perdana sebelum mengadakan sosialisasi dengan warga Kelurahan Cibeureum dilakukan secara daring dengan mengundang kader ke dalam grup WhatsApp. Ketika mengumumkan mengenai program ini, terdapat beberapa tanggapan yang menanyakan mengenai keresmian program ini. Sebagai tindak lanjut, kami mengirimkan surat izin penelitian dari Dinas Kesehatan Kota Cimahi dan ethical clearance dari Komite Etik Penelitian Universitas Padjadjaran sebagai bukti keresmian kegiatan ini.

c. Saat sosialisasi program ini kepada kader, kami mengalami beberapa kendala mengenai waktu. Melihat ketersediaan waktu dan tempat pihak puskesmas dan situasi COVID-19 ini, kami harus melakukan sosialisasi dalam 3 (tiga) kloter dengan masingmasing kloter hanya mendapatkan waktu sekitar 3 (tiga) jam untuk melakukan sosialisasi tatap muka. Hal ini kami atasi dengan mengirimkan ulang materi ke grup WhatsApp dan membuat panduan pengisian formulir.

d. Terdapat hambatan yang kami alami berupa adanya beberapa kader di RW tertentu yang kurang responsif terhadap program KKN ADA AMARI COVID19 ini, misalnya tidak membalas pesan, tidak mengisi formulir survei, dan sebagainya. Terdapat beberapa RW yang tidak mengisi formulir sama sekali dibuktikan dengan tidak adanya data yang terdata di REDCap, yaitu dari RW 12 dan 27.

Terdapat beberapa perkiraan mengenai penyebab munculnya hambatan ini berdasarkan tanggapan warga di grup WhatsApp:

1. Walaupun kami sudah mengusahakan untuk mengajarkan digital literacy kepada warga, namun tidak semua warga memiliki digital literacy yang baik. Terdapat pula warga yang memiliki kendala pada penggunaan alat komunikasi (tidak punya ataupun rusak).

2. Terdapat warga yang mengatakan bahwa terdapat pengalaman terdahulu di mana 
data pribadi warga dibocorkan sehingga warga tidak ingin menuliskan beberapa data pribadi dirinya, misalnya nomor telepon. Kami sudah mencoba untuk menjelaskan bahwa data pribadi mereka tidak akan dipublikasikan, namun masih terdapat warga yang skeptis.

\section{Rencana Tindak Lanjut berdasarkan Permasalahan atau Hambatan}

Terdapat beberapa rencana tindak lanjut yang telah, sedang, atau akan kami lakukan terhadap masalah yang belum selesai. Pada bagian ini, tindak lanjut yang dipaparkan adalah tindak lanjut kami pribadi, bukan berupa saran rekomendasi kepada pihak ADA AMARI COVID-19. Tindak lanjut tersebut adalah sebagai berikut:

a. Menyusun laporan akhir individu dan kelompok untuk diberikan ke pihak Universitas Padjadjaran dan pihak ADA AMARI COVID-19 sebagai bentuk pertanggungjawaban pelaksanaan KKN ini.

b. Menyelesaikan pendataan survei formulir ADA AMARI COVID19 , termasuk cleaning dan validasi data.

c. Menyampaikan kepada pihakpihak terkait (pihak puskesmas dan kader) bahwa program KKN ADA AMARI COVID-19 ini berakhir dan menjelaskan bahwa program ini akan dilanjutkan oleh pihak ADA AMARI COVID-19 dan telehealth. Selain itu, kami juga menyampaikan bahwa data ini masih dapat diakses dan dilanjutkan oleh warga Kelurahan Cibeureum.

d. Laporan kelompok dan data Kelurahan Cibeureum yang final akan diberikan ke pihak puskesmas.

\section{SIMPULAN}

KKN Tema Kemanusiaan ADA AMARI COVID-19 yang berlokasi di Kelurahan Cibeureum, berhasil mengumpulkan data sebanyak 516 data per tanggal 30 Juli 2020. Mahasiswa Unpad telah mampu mengintegrasikan kemampuan berinteraksi dengan mahasiswa berbeda disiplin ilmu dan masyarakat Kelurahan Cibeureum Kota Cimahi, mampu meningkatkan wawasan, empati, sikap serta perilaku sosial secara baik melalui kegiatan terintegrasi penelitian masingmasing DPL, dapat memiliki rasa tanggung jawab sebagai generasi penerus bangsa dengan melaksanakan pengabdian kepada masyarakat sekitar, dan mampu membantu pendataan terhadap permasalahan yang dialami oleh masyarakat Kelurahan Cibeureum yaitu kondisi kesehatan di masa pandemi melalui program ADA AMARI COVID-19.

Dengan terjalinnya komunikasi yang baik antara mahasiswa dengan kader yang mewakili masyarakat, mahasiswa menjadi lebih optimal menjalankan peran serta fungsinya sebagai relawan dalam penanggulangan pandemi COVID-19 sebagaimana yang telah menjadi fokus utama dari Program ADA AMARI COVID-19 Universitas Padjadjaran. Capaian data tersebut tidak terlepas dari peran aktif mahasiswa dan kader yang secara sukarela bekerja sama dalam proses pengambilan data sampai validasi data. Namun, penulis menyadari dalam pelaksanaannya masih terdapat kendala yang membuat data yang didapat belum sesuai dengan target yang diharapkan, di antaranya terdapat masyarakat yang kurang responsif terhadap program AMARI, serta tidak terdapatnya kader dari 4 RW yang ditunjuk sebagai perwakilan. Selain itu, kendala dalam hal teknis pun turut berpengaruh seperti halnya kendala dalam mengakses internet, kepemilikan dan penggunaan smartphone, digital literasi, dan kurangnya kepercayaan terhadap keamanan data pribadi yang akan diisi dalam formulir survei ADA AMARI COVID-19. 
Terdapat beberapa rekomendasi yang kami ajukan untuk perbaikan program ini ke depannya maupun menjadi masukan bagi pihak ADA AMARI COVID-19 Unpad dalam melaksanakan program telehealth. Pertama, pengadaan formulir dalam bentuk fisik perlu dibuat agar program ini ke depannya dapat dijangkau lebih banyak masyarakat. Kedua, perlunya imbauan dari pihak kelurahan kepada masing-masing ketua RW untuk ikut berpartisipasi pada program ini secara tertulis yang juga berisi kepastian bahwa keamanan data pribadi dijamin sehingga masyarakat dapat lebih percaya dan berpartisipasi aktif dalam program ini. Terakhir agar pengisian data survei dapat mencapai lebih banyak masyarakat, diperlukan adanya kontribusi lebih dari berbagai pihak, seperti pihak Kelurahan dan Puskesmas untuk memastikan telah tersedianya perwakilan kader dari setiap RW yang akan membantu pelaksanaan Program AMARI ini serta dapat berkontribusi dalam penyampaian program AMARI agar masyarakat dapat lebih responsif terhadap program ini.

\section{DAFTAR PUSTAKA}

ADA AMARI COVID-19 Unpad. (n.d.). KKN Tema Kemanusiaan ADA AMARICOVID-19. (http://amariunpad.id/adaamari, diakses pada 27 Juli 2020)

BPS Kota Cimahi. 2018. Kecamatan Cimahi Selatan dalam Angka 2018. (https://cimahikota.bps.go.id/publication /2018/09/26/ac4859cee662783bb810090 4/kecamatan-cimahi-selatan-dalamangka-2018.html, diakses pada 27 Juli 2020).

Diah Handayani, Dwi Rendra Hadi, Fathiyah Isbaniah, Erlina Burhan, Heidy Agustin, Penyakit Virus Corona 2019, JURNAL RESPIROLOGI INDONESIA, Vol. 40, No. 22020.

Gunawan, W., \& Kusuma, D. A. (2021). Kegiatan Pemberian Bantuan Sosial Pandemi Covid-19 Di Desa Sekitar Kampus Unpad Jatinangor. Kumawula: Jurnal Pengabdian Kepada Masyarakat, $3(3)$, 465. https://doi.org/10.24198/kumawula.v3i3. $\underline{28626}$

Kader KKN Cimahi. 2020. (Diakses pada 27 Juli 2020).

Karyono, Rohadin, Devia Indriayani, Penangangan dan Pencegahan Pandemi Wabah Virus Corona (COVID-19)

Kabupaten Indramayu, Jurnal Kolaborasi Resolusi Konflik, Vol. 2 No. 2, 2020.

Lawrenche, F., Wulandari, N., Ramadhan, N., Rahayu, F., Bakhtiar, M. A., \& Nurrachmawati, A. (2020).

Pemberdayaan Masyarakat Dimasa Pandemi Covid-19 Pada Ikatan Remaja Masjid RT.04 Loa Kulu. Kumawula: Jurnal Pengabdian Kepada Masyarakat, 3(3), 429-434.

https://doi.org/10.24198/kumawula.v3i3. 28007

Pedoman Survei AMARI dan REDCap. 2020. (Diakses pada 28 Juli 2020).

Pemerintah Kota Cimahi. (n.d.). Kecamatan dan Kelurahan.

(https://cimahikota.go.id/page/detail/16, diakses pada 27 Juli 2020)

Peraturan Wali Kota Cimahi Nomor 13 Tahun 2019 tentang Batas Wilayah Kelurahan Kota Cimahi. (https://peraturan.bpk.go.id/Home/Detail s/135191/perwali-kota-cimahi-no-13tahun-2019Pusat Informasi COVID-19 Kota Cimahi. 2020.

Peta Sebaran COVID-19 per Kecamatan dan Kelurahan, (https://covid19.cimahikota.go.id//infogr afis, diakses pada 27 Juli 2020)

Syafrida, Ralang Hartati, Bersama Melawan Virus Covid 19 di Indonesia, SALAM; Jurnal Sosial \& Budaya Syar-i FSH UIN Syarif Hidayatullah Jakarta Vol. 7 No. 6 (2020).

Worldometer. 2020. COVID-19 Coronavirus Pandemic.

(https://www.worldometers.info/coronav irus/\#countries, diakses pada 27 Juli 2020).

Yuliana, Corona Virus Diseases (COVID-19) Sebuah Tinjaun Literatur, Wellness And Heathy Magazine, Vol.2 No.1, 2020. 
Ziyan Afriliyanti Nafilah, Muflihah, Langkah Taktis Pencegahan COVID-19 Di Desa Lowayu Kecamatan Dukun Kabupaten Gresik, Prosiding Penelitian \& Pengabdian Kepada Masyarakat (Jurnal Unpad), Vol. 7 No. 2, 2020) 